\title{
PENINGKATAN KOMPETENSI TATA BAHASA PRANCIS MAHASISWA JURUSAN PENDIDIKAN BAHASA PRANCIS FBS UNY DENGAN MODEL PEMBELAJARAN INQUIRY
}

\author{
Nuning Catur SW., Siti Sumiyati, Anggraini Dora TA., Titis Dwiyuliani \\ Universitas Negeri Yogyakarta \\ email: nuning@uny.ac.id
}

\begin{abstract}
(Title: Improving French Grammar Competence of The Students at French Departement, Faculty of Languages and The Arts, Yogyakarta State Uninersity Through The Inquiry Model). This research aimed to improve the students' French grammar competence through the Inquiry model with seven steps, ie : developing a question, generating a hypothesis, developing an experimental desain, collecting and recording data, analizing data, reaching conclusions, forming and extending generalizations, communicating results. This research was a class room action reseach study conducted in two cycles from the 2th to 27th May 2016. The research subjects were 21 students attending in Grammaire 4 in classes E and J at the French Departement, Faculty of Languages and the Arts, Yogyakarta State University. The data were collected through observations, field notes, and achievement test. They were analized using qualicative and quantitative descriptive techniques. The results of the study showed that the application of the inquiry model was capable of improving the students's French grammar learning, both in the process and the product. The success in the process was indicated by student's activeness in the learning activities for the Grammaire 4 through the inquiry model, and the average attainment in the first cycle was $70.47 \%$ and $77.1 \%$ in second cycle. The success in product was indicated by improvement of the students'French grammar competence, reflected by the improvement of average score of post-test. The difference between the average score of pre-test and post-test scores was significant because the result of the paired sample t-test both in the first cycle and second one was $\mathrm{p}(0.001)<0.05$.
\end{abstract}

Keywords: inquiry model, French grammar, action research

\section{PENDAHULUAN}

Keterampilan berbahasa secara reseptif dan produktif meliputi menyimak, berbicara, membaca, dan menulis. Demikian pula dalam bahasa Prancis, keempat kompetensi berbahasa ini memerlukan tata bahasa yang memadai agar kompetensi pembelajar dapat berkembang. Penguasaan tata bahasa Prancis ini terintegrasi pada keempat keterampilan berbahasa tersebut, dengan menggunakan pendekatan komunikatif berazaskan tindakan, dan disajikan secara induktif. Dengan demikian pembelajar bahasa Prancis dibiasakan untuk belajar secara globaliste, dan bukan secara sérialiste (CECRL, 2001: 89) Kompetensi berbahasa tersebut tidak hanya dalam hal ketepatan berbahasa, namun juga dalam hal keindahan berbahasa Prancis. Oleh sebab itu, pembelajaran tata bahasa Prancis atau grammaire français tidak hanya mem- butuhkan unsur bentuk, fungsi, dan makna namun juga penggunaannya dalam konteks agar pembelajar dapat berkomunikasi sesuai dengan kebutuhan.

Kompetensi tata bahasa Prancis mahasiswa di Jurusan Pendidikan Bahasa Prancis FBS UNY ditumbuhkembangkan selama 5 (lima) semester berturut-turut. Terkait dengan kompetensi berbahasa Prancis standard international, semester IV merupakan awal pembelajaran bahasa Prancis niveau B1, yaitu tingkat pembelajar bahasa Prancis mandiri pemula. Maksud dari mandiri pemula yaitu mandiri namun masih dalam pantauan atau bimbingan pengajarnya. Le Conseil de l'Europe (2001: 90) mendeskripkan kompetensi tata bahasa Prancis pada niveau B1 sebagai berikut. Pertama, mampu menggunakan sejumlah struktur kalimat dan ekspresi yang sering digunakan 
dan menerapakannya dalam situasi yang tepat. Kedua, mampu berkomunikasi dengan kebenaran gramatikal yang memadai dalam konteks situasi, yaitu penguasaan tata bahasa yang baik, meskipun masih ada pengaruh bahasa ibu, kekeliruan yang dilakukan tidak berpengaruh pada kejelasan makna pada umumnya.

Dengan kata lain, kompetensi tata bahasa Prancis pembelajar dapat dijabarkan sebagai berikut. Pertama, dapat mengonstruksikan konsep unsur tata bahasa Prancis yang dipelajari. Kedua, dapat memproduksi kalimat dan ekspresi dengan tepat sesuai konteksnya. Ketiga, dapat mereformulasikan kalimat dan ekspresi dengan tepat sesuai konteksnya.

Namun dalam kenyataannya, pada suatu kelas mata kuliah Grammaire 4 sebagian besar masih membutuhkan bimbingan penuh dari dosen. Empat belas dari dua puluh satu mahasiswa cenderung diam selama proses pembelajaran. Walaupun sampai dengan perkuliahan pada tatap muka keenam mereka mampu mengerjakan latihan dari buku teks., namun demikian 7 di antara 11 mahasiswa untuk nilai tugas dan quiz belum mencapai nilai $\mathrm{B}$, sedangkan di kelas lain terdapat 7 di antara 10 yang belum mencapai nilai B.

Grammaire merupakan suatu sistem formal yang disusun oleh para ahli bahasa untuk mengembangkan mekanisme yang mampu memproduksi kalimat-kalimat yang diakui benar oleh para pengguna bahasa (Gallison dan Coste, 1976: 253). Adapun dalam dunia pembelajaran bahasa, Cuq (1996: 41) menyatakan adanya dua sudut pandang tentang grammaire. Pertama, penguasaan grammaire merupakan hasil dari aktivitas membangun konsep. Aktivitas ini membuat pembelajar menciptakan sendiri suatu gambaran metalinguistik yang diatur oleh bahasa yang dipelajarinya. Kedua, pengarahan dari pengajar pada aktivitas ini adalah mengkinerjakan representasi metalinguistik yang dimaksud. Dari kedua pendapat tersebut dapat dipahami bahwa dalam pembelajaran grammaire tugas pengajar tidak hanya mengarahkan pembelajar agar mampu membangun konstruk kognisi akan tetapi juga mengarahkan mereka untuk menggunakan grammaire dengan benar untuk berkomunikasi dalam kehidupan nyata.
Dalam kenyataannya, mahasiswa masih melakukan kekeliruan dalam morfosintaksis dan pola kalimat, bahkan kekeliruan morfosintaksis yang mendasar. Kekeliruan yang mereka lakukan menunjukkan bahwa mahasiswa masih belum cermat dalam menggunakan tata bahasa Prancis. Selain itu, kekeliruan tersebut juga menunjukkan bahwa mahasiswa belum memahami konsep atau mungkin belum mampu membangun konstruk kognisinya. Tagliante (2006: 154) menyatakan bahwa penguasaan konsep gramatika merupakan aktivitas yang menandai adanya komunikasi. Aktivitas ini memberikan kemampuan intelektual menengah dan tinggi yang meliputimengalisis suatu pemikiran, menyimpulkan, dan sintesis. Pembelajaran ini mengarahkan mahasiswa untuk merefleksi dokumen (corpus) yang dipelajari dan dokumen tersebut berisikan berbagai unsur gramatika (occurences du point grammatical). Kemudian, mahasiswa diarahkan untuk memfokuskan pengetahuan gramatikalnya untuk melakukan komunikasi sebagaimana yang ditemukan dalam konteks dokumen otentiknya (Tagliante, 2006: 155). Untuk aktivitas pengayaannya dapat digunakan model dialog pendek dengan tujuan untuk (1) mempraktikkan struktur kalimat secara intensif dalam situasi komunikasi, (2) menggunakan kosa kata dan tema yang sesuai dengan konteks, dan (3) memprioritaskan penggunaan struktur kalimat tertentu (Tagliante, 2006: 158).

Upaya agar mahasiswa mampu membangun konstruk kognisi dan belajar sendiri merupakan hal yang mendesak sehingga mahasiwa dapat mengatasi kelemahan mereka. Untuk mengatasi permasalan itu, peneliti mencoba menggunakan model inquiry. Model inquiry dipilih karena model pembelajaran ini mengarahkan mahasiswa untuk mencari informasi sendiri, menganalisis informasi sendiri untuk menjawab pertanyaan mengapa demikian, dan berpikir kritis dengan mengajukan pertanyaan dan mencari jawaban sendiri (Joyce et al, 2016: 345). Dengan penerapan model inqui$r y$ yang disertai dengan pertanyaan arahan dalam proses pembelajaran diharapkan mahasiwa dapat membangun konstruksi kognisinya.

Model inquiry merupakan salah satu model pembelajaran yang dilandasi oleh teori 
belajar konstruktivistik. Pembelajaran lebih dicirikan oleh aktivitas eksperimen, pertanyaan-pertanyaan, investigasi, hipotesis, dan model-model yang dibangkitkan oleh peserta didik sendiri (Suryaman, 2012: 50). Lebih lanjut Van Galserfeld (melalui Budiningsih, 2005: 57) mengemukakan tiga kemampuan yang diperlukan dalam proses mengonstruksi pengetahuan, yaitu: 1) kemampuan mengingat dan mengungkapkan kembali pengalaman, 2) kemampuan membandingkan dan mengambil keputusan akan kesamaan dan perbedaan, dan 3) kemampuan untuk lebih menyukai suatu pengalaman yang satu dari pada lainnya.

Model inquiry dikembangkan oleh Suchman (1981) untuk membantu para siswa mengembangkan disiplin intelektual dan keterampilannya untuk memunculkan pertanyaan dan mencari jawaban dari pertanyaan tersebut (Joyce et al, 2016: 345). Senada dengan gagasan Suchman, Kulthau (2010: 18) menyatakan bahwa model inquiry dapat mengembangkan cara berfikir aktif mahasiswa. Pada proses pembelajaran mahasiswa mencari informasi sendiri untuk mencari jawaban dari suatu pertanyaan atau permasalahan berdasarkan temuannya sendiri. Lebih lanjut Joyce et al (2004: 6-7) menyatakan bahwa model inquiry mengembangkan cara berfikir mahasiwa menjadi lebih aktif. Dengan mencari dan menemukan sendiri, temuan-temuan yang diperoleh akan lebih lama berada dalam ingatan mereka dan akan sulit terlupakan. Pembelajaran yang menggunakan model ini mengarahkan mahasiswa untuk menemukan pengetahuan, mengungkapkan kenyataan, dan membuat simpulan sesuai dengan struktur pengetahuan yang dimiliki. Dell'Olio dan Donk (2007: 320) juga menyatakan bahwa pembelajaran berbasis inquiry membuat pengalaman mahasiswa selama bergelut dengan suatu pertanyaan atau permasalahan, terlibat dalam prosedur yang sistemis untuk memecahkan permasalahan, dan mengkomuikasikan temuannnya kepada mahasiswa lain.

Agar mahasiswa mampu mencari pemahaman dalam dan perspektif individu di tengah banyaknya informasi yang tersedia saat ini, Kulthau (2010: 18) menyarankan guided inquiry dengan pertimbangan bahwa (1) mahasiwa memerlukan bimbingan dan intervensi agar mampu belajar secara mendalam, (2) tanpa bimbingan mahasiswa sering menganggap ringan proses pembelajaran inquiry, yakni hanya dengan menggumpulkan data dan mempresentasikan tugas, (3) dengan bimbingan mahasiswa mampu berkonsentrasi pada mengonstruksi pengetahuan pada proses inquiry sehingga mencapai pemahaman yang perorangan dan mentrasferkannya dalam keterampilan, dan (4) mahasiswa merasa berperan penting dalam proses inquiry.

Student Achivement Divisions (2013:

2) menyimpulkan karakteritik model inquiry sebagai berikut. Pertama, proses pembelajaran meliputi penemuan permasalahan dan penemuan jawaban dari permasalahan tersebut. Hal inilah yang dapat memunculkan sikap analitis dan kritis untuk mengajukan hipotesis berupa pertanyaan yang diajukan setiap kelompok. Kedua, mahasiswa terlibat dalam kelompok kecil untuk penemuan sebagai jawaban dari suatu pertanyaan atau permasalahan. Ketiga, temuan yang diperoleh nyata dan logis sehingga membuat mahasiswa kreatif dalam pemecahan masalah. Keempat, pengajar merespon kebutuhan belajar mahasiswa dan mengetahui kapan dan bagaimana membuat mahasiswa bergerak maju dalam inquiry-mereka. Kelima, pengajar berperan aktif untuk mambangun budaya dimana gagasan diperdebatkan secara sopan, dicek ulang, ditegaskan ulang dan ditinjau kembali.

Dell'Olio dan Donk (2007: 330-335) menyatakan prosedur pembelajaran model inquiry melalui tahap-tahap berikut.

Tahap pertama: Developing a question. Pada tahap ini pembelajaran dimulai pengajar mengajukan pertanyaan yang diungkapkan dengan jelas sehingga mahasiswa mampu menemukan jawaban berdasarkan pengalaman dan pengetahuannya. Berdasarkan pertanyaan yang diajukan mahaiswa mengembangkan pertanyaannya sendiri.

Tahap kedua: Generating a hypothesis. Pada tahap kedua, dengan menggunakan pengetahuan yang telah dimiliki dan pemahaman yang terkait dengan pertanyaan yang sudah diperkirakan jawabannya, mahasiwa membangun hipotesis mereka. 
Tahap ketiga: Developing an experimental design. Pada tahap ketiga, mahasiswa mendesain percobaan mereka untuk menguji hipotesis dan membatu mereka untuk membangun konsep kognitif.

Tahap keempat: Collecting and recording data. Pada tahap keempat, mahasiswa mengumpulkan data dan mencatat data. Pada tahap ini mahasiswa juga sekaligus menampilkan data dengan jelas.

Tahap kelima: Analyzing data. Pada tahap kelima, mahasiswa nganalisis data baik data yang dikumpulkan sendiri maupun data yang diberikan oleh pengajar, kemudian menjawab pertanyaan inquiry mereka.

Tahap keenam: Reaching conclusions, forming and extending generalizations. Pada tahap keenam, mahasiswa membandingkan hasil yang ditemukan dengan hipotesis yang mereka buat pada awal perkuliahan. Dengan demikian, mahasiswa menjawab pertanyaan: (1) Apakah hasil eksperimen mereka bermanfaat?
Kenapa?, (2) Apakah hasil temuan mereka dapat membatu dalam penerapan pengetahuannya secara nyata?, (3) Dapatkah mereka membuat generalisasi berdasarkan hasil temuan mereka?, Dan (4) Apa saja yang kiranya dapat diketahui berdasarkan hasil temuan mereka?

Tahap ketujuh: Communicating results. Pada tahap terakhir ini, mahasiswa mengkomunikasikan hal yang telah mereka pelajari melalui presentasi.

Pada penelitian ini ketujuh tahap model inquiry tersebut dilakasanakan. Oleh karena indikator keberhasilan produk penelitian tindakan ini adalah nilai kompetensi tata bahasa Prancis mahasiswa, maka pada tahap keenam mahasiswa menyelesaikan latihan yang ada dalam buku teks (Girardet dan Pêcheur, 2008) agar dapat menjawab pertanyaan nomer 2, yaitu: Apakah hasil temuan mereka dapat membantu dalam penerapan pengetahuannya secara nyata? Ketujuh tahapan tersebut dipaparkan pada Gambar 1.



Tujuan dari tulisan ini adalah mengetahui peningkatan kompetensi tata bahasa Prancis mahasiswa semester IV Jurusan Pendidikan Bahasa Prancis FBS UNYdengan model inqui$r y$, dalam suatu PTK.

\section{METODE}

Penelitian ini merupakan Penelitian Tindakan Kelas (PTK) atau classroom action research) yang dilakukan dalam dua siklus dan bersifat kolaboratis, dengan seorang peneliti bersama dua dosen pengampu mata kuliah Grammaire 4 dan dua dosen bahasa Prancis. Arikunto (2010: 129) menyatakan bahwa PTK merupakan penelitian tentang hal-

hal yang terjadi di masyarakat atau kelompok sasaran, dan hasilnya langsung dikenakan pada masyarakat yang bersangkutan. Dalam penelitian masyarakat yang dimaksud adalah mahasiswa Jurusan Pendidikan Bahasa Prancis FBS UNY.

Menurut Kemmis dan Mc Taggart (via Madya, 2011: 67), desain penelitian tindakan kelas dengan model ini mencakup empat tahapan, yaitu perencanaan (plan), tindakan (act), observasi (observe), dan refleksi (reflect). Penelitian tindakan kelas ini bersifat siklus dan spiral. Dengan model ini, jika dalam awal pelaksanaan tindakan didapati kekurangan perencanaan dan pelaksanaan dapat dilakukan 
pada siklus berikutnya sampai target tercapai. Keempat tahapan dalam penelitian tersebut dapat diuraikan berikut.

Pertama, perencanaan yakni tindakan yang dilakukan untuk meningkatkan kompetensi tata bahasa Prancis mahasiswa. Pada tahap ini peneliti dan kolaborator berdiskusi dan berkolaborasi untuk mengidentifikasi permasalahan dalam pembelajaran Grammaire 4. Identifikasi tersebut dilakukan dengan melakukan observasi proses belajar mengajar di kelas. Observasi dilakukan untuk megetahui proses kegiatan proses belajar mengajar Grammaire 4 di kelas, aktivitas yang dilakukan mahasiswa dan suasana kelas saat kegiatanbelajar mengajar berlangsung.

Kedua, tindakan yakni kegiatan pembelajaran dengan menggunakan model Inquiry sebagai upaya meningkatkan kompetensi tata bahasa Prancis.

Ketiga, observasi (pengamatan) adalah pengamatan yang dilakukan peneliti terhadap keaktifan mahasiswa dalam proses pembelajaran.

Keempat, refleksi merupakan kegiatan mengkaji dan mempertimbangkan hasil yang diperoleh dari pengamatan sehingga dapat dilakukan revisi terhadap proses pembelajaran berikutnnya. Proses PTK disajikan pada Gambar 2.

Subjek Penelitian adalah 21 mahasiswa Jurusan Pendidikan Bahasa Prancis, FBS UNY semester empat, yang mengikuti mata kuliah Grammaire IV yaitu kelas E (10 mahasiswa) dan kelas J (11 mahasiswa). Penelitian dilaksanakan di Jurusan Pendidikan Bahasa Prancis FBS UNY, pada 2-26 Mei 2016.

Prosedur Penelitian PTK ini dilakukan dengan empat tahap sebagai berikut. Tahap pertama, peneliti bersama-sama dengan anggota peneliti melakukan identifikasi masalah yang muncul berkaitan dengan situasi pembelajaran dan hubungan antar mahasiswa yang mengikuti mata kuliah Grammaire 4.

Tahap kedua, berdasarkan hasil identifikasi masalah pada tahap pertama, peneliti melakukan tindakan yang telah direncanakan dan disepakati dengan kelompok peneliti. Beberapa kegiatan yang telah direncanakan adalah: (1) membuat skenario pembelajaran, (2)

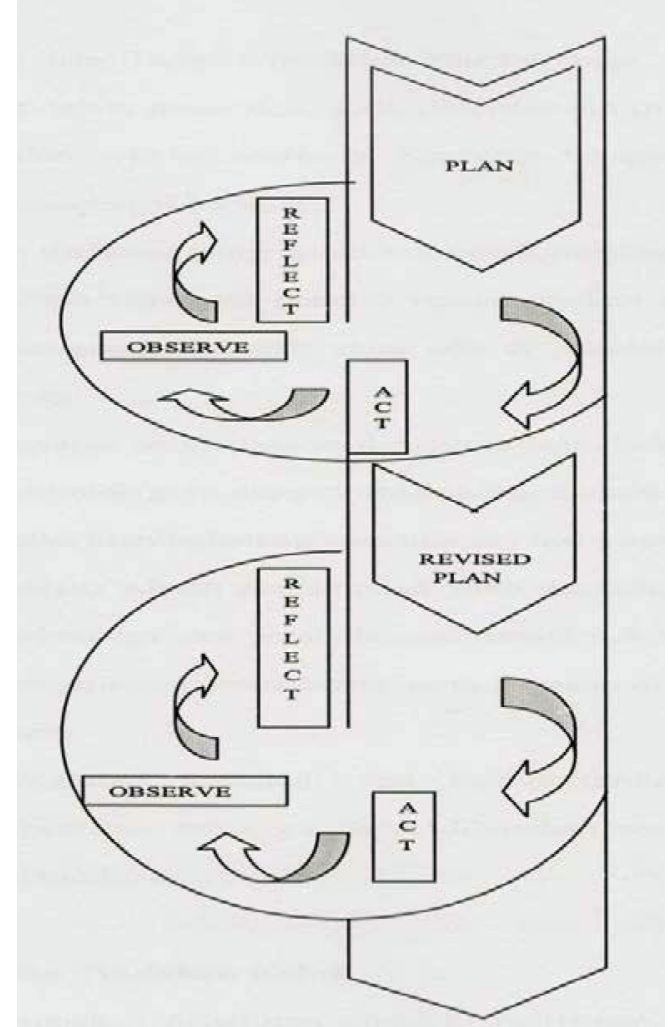

Gambar 2. Skema PTK Model Kemmis dan Mc. Taggart (Madya, 2011: 67)

membuat lembar observasi untuk mengetahui kondisi kegiatan belajar mengajar di kelas, (3) membuat alat bantu yang diperlukan untuk mengoptimalkan pembelajaran mahasiswa, dan (4) membuat alat evaluasi.

Tahap ketiga, peneliti bersama-sama kelompok melakukan observasi, monitoring, dan evaluasi terhadap pelaksanaan tindakan yang telah dilakukan. Kriteria keberhasilan tindakan adalah bahwa mahasiswa semakin baik dalam pembelajaran inquiry dan menguasai tata bahasa Prancis.

Tahap keempat, yakni refleksi, tim peneliti melakukan analisis dan sintesis hasil kegiatan observasi. Hasil ini akan dipergunakan sebagai acuan untuk merencanakan siklus selanjutnya, merevisi atau merencanakan jenis tindakan berikutnya yang perlu diterapkan agar hasil yang diharapkan dapat sesuai yang diinginkan.

Data dikumpulkan dengan teknik tes dan nontes. Teknik tes tertulis digunakan untuk mengungkap tingkat penguasaan tata bahasa 
Prancis mahasiswa. Teknik nontes digunakan untuk mengukur aspek afektif dan psikomotorik. Teknik nontes menggunakan observasi dan catatan lapangan untuk mengungkap secara deskriptif pelaksanaan tindakan dalam rangka peningkatan partisipasi mahasiswa dalam proses pembelajaran dan kompetensi tata bahasa Prancis mahasiswa. Observasi dan dokumentasi dilaksanakan selama mahasiswa melakukan perkuliahan Grammaire 4.

Analisis dalam PTK ini adalah deskriptif kualitatif dan kuantitatif. Deskriptif kualitatif digunakan untuk mengtahui secara rinci peningkatan keaktifan mahasiswa dalam proses pembelajaran Grammaire 4 dengan model inquiry yang dikembangkan oleh Dell'Olio dan Donk (2007: 330-335). Analisis ini dilakukan selama proses tindakan. Deskriptif kuantitatif digunakan untuk mengukur peningkatan kompetensi tata bahasa Prancis mahasiswa terhadap materi yang terdapat dalam bahan perkuliahan, yakni berupa pengamatan terhadap skor mahasiswa. Pada penelitian ini peneliti mengumpulkan data dengan melakukan tes tertulis untuk melihat penguasaan tata bahasa Prancis yang telah dipelajari dengan model inquiry. Tes yang dilakukan adalah tes awal (pre-test), post-test pada siklus I, dan post-test pada siklus II. Peneliti juga menggunakan lembar observasi dan catatan lapangan untuk melihat aktivitas belajar mahasiswa selama proses perkuliahan berlangsung. Teknik ini digunakan untuk mengetahui secara lebih rinci kegiatan proses pembelajaran yang menggunakan model inquiry.

Pada dasarnya ada dua kelompok data yang akan dianalisis dalam penelitian ini. Kedua data tersebut adalah hasil observasi proses kegiatan perkuliahan dan data hasil belajar mahasiswa yang diperoleh dari hasil tes setiap akhir siklus. Berdasarkan kedua data tersebut analisis yang dilakukan adalah: (1) untuk data hasil observasi proses kegiatan perkuliahan, data jumlah mahasiswa yang terlibat dalam masing-masing aktivitas dipersentasekan (Arikunto, 2013: 272); (2) data hasil belajar mahasiswa yang diperoleh dari hasil tes setiap akhir siklus akan dianalisis untuk melihat ketuntasan belajar mahasiswa secara individu. Pada penelitian ini Kriteria Ketuntasan Minimal (KKM) pada mata kuliah Grammaire 4 adalah 71.
Instrumen Penelitian terdiri atas dua bentuk, yakni insttumen tes bahasa Perancis dan lembar obervasi. Tes tata bahasa Prancis digunakan untuk mengukur keberhasilan mahasiswa sebelum dan setelah mengikuti tindakan kegiatan belajar dengan menggunakan model inquiry. Tes hasil belajar yang disusun adalah bentuk isian dan mereformulasikan kalimat. Lembar observasi digunakan untuk mencatat dan mengetahui aktivitas mahasiswa pada perkuliahan Grammaire 4. Observasi dilakukan oleh: (1) dosen dan juga bertindak sebagai observer, (2) anggota peneliti observer dan kolaborator. Berikut ini kisi-kisi dari aspek yang diamati pada lembar observasi (The Student Achievement Divisions, 2013: 6).

Pertama, perencanaan pembelajaran. Aspek ini diamati dengan empat indikator (indikator 1-4), yaitu: (a) menemukan kaitan materi yang dipelajari dengan materi yang telah diketahui, (b) mengajukan pertanyaan atau permasalahan untuk pemahaman lebih lanjut, (c) mengajukan jawaban atau solusi, dan (d) menemukan langkah-langkah awal selanjutnya untuk melaksanakan inquiry.

Kedua, kemajuan aktivitas belajar. Aspek ini meliputi tiga indikator (indikator 5-7), yaitu: (a) menunjukkan kemajuan dalam proses belajar, (b) berdiskusi dalam kelompok dan mempresentasikan temuannya, dan (c) memberikan solusi pada permasalahan yang ditemui mahasiswa lain.

Ketiga, efleksi terhahap materi yang dipelajari untuk menguatkan inquiry-nya. Aspek ini meliputi tiga indikator (indikator 8-10), yaitu: (a) menunjukkan bahwa mahasiswa telah mencapai tujuan pembelajaran, (b) mnemukan upaya untuk mengatasi kendala yang kemungkinan ditemui, dan (c) menyatakan bahwa langkah-langkah inquiry yang dilakukan memandunya untuk mengatasi permasalahan baru yang ditemui.

Catatan lapangan dibuat oleh observer, kemudian hasilnya didiskusikan dengan peneliti. Catatan lapangan adalah catatan tertulis mengenai apa yang didengar, dilihat, dialami ,dan dipikirkan dalam proses pengumpulan data dan merupakan refleksi terhadap data penelitian. Peneliti memiliki catatan lapangan untuk dasar analisis karena data lapangan yang sa- 
ngat banyak tidak mungkin dihapal oleh peneliti (Moleong, 2014: 210-211). Hal-hal yang diperhatikan sebelum membuat catatan lapangan, yaitu: (a) aktivitas mahasiswa selama kegiatan perkuliahan, (b) aktivitas pada awal kegiatan perkuliahan, (c) aktivitas pada proses kegiatan perkuliahan, (d) aktivitas pada akhir kegiatan perkuliahan, (e) kendala atau kesulitan dalam kegiatan perkuliahan, dan (e) solusi dan saran

Indikator keberhasilan PTK ini adalah apabila terjadi peningkatan kompetensi tata bahasa Prancis mahasiswa. Hal ini ditunjukkan dengan adanya peningkatan nilai mahasiswa dari sebelum dilakukan tindakan dengan setelah dilakukannya tindakan di dalam kelas. Kriteria keberhasilan penelitian tindakan kelas meliputi dua hal, yaitu keberhasilan proses dan keberhasilan produk.

Keberhasilan proses dilihat dari tindak belajar atau perkembangan proses belajar mahasiswa pada perkuliahan dengan menggunakan model inquiry. Indikator keberhasilan proses meliputi tindak belajar mahasiswa pada proses: (1) perencanaan perkuliahan (planning the course), (2) pemantauan kemajuan (monitoring progress), dan (3) refleksi terhahap materi yang telah dipelajari untuk memperkuat inquiry-nya (reflecting on lessons learned to consolidiate inquiry), (The Student Achievement Divisions, 2013 : 6).

Indikator keberhasilan produk ini diperoleh jika terjadi peningkatan prestasi (nilai) subjek penelitian sebelum diberi tindakan dan sesudah diberi tindakan. Indikator keberhasilan nilai dalam penelitian ini adalah mahasiswa mampu meningkatkan kompetensi tata bahasa Prancis. Peningkatan hasil belajar mahasiswa dapat dikatakan berhasil apabila pencapaian nilai adalah 71. Diharapkan hasil belajar mahasiswa yang memenuhi nilai KKM dapat melebihi $70 \%$ dari jumlah mahasiswa.

\section{HASIL DAN PEMBAHASAN Hasil \\ Pelaksanaan Pratindakan.}

Pertama, perencanaan, yakni kegiatan yang dilakukan oleh peneliti dan kolaborator ini meliputi koordinasi pelaksanaan obervasi yang dilaksanakan dua kali pertemuan. Kedua, pelaksanaaan, yakni observasi pratindakan di- lakukan sebanyak dua kali, yaitu Senin, 2 Mei 2016 pada pukul 11.10-12.50 dan Selasa 3 Mei 2016 pada pukul 09.20-11.00. Pada kegiatan ini peneliti mengajar dengan metode Cooperative learning. Kegiatan dimulai oleh peneliti dengan memberitahukan bahwa kehadiran kolaborator dan mahasiswa anggota peneliti bertujuan untuk melaksanakan observasi karena kelas dipakai sebagai sampel penelitian tindakan. Ketiga, pengamatan yakni kegiatan pembelajaran selama pratindakan berjalan lancar. Mahasiwa dapat menyelesaikan latihan-latihan yang diberikan.

Keaktifan mahasiwa perlu ditingkatkan karena hal-hal berikut. Pertama, sebagian besar mahasiswa cenderung diam, hanya enam di antara dua puluh satu mahasiswa yang aktif pada proses pembelajaran. Kedua, mahasiswa menjawab apabila diberi pancingan, Keempat, mahasiswa menjawab apabila ditunjuk. Kelima, mahasiswa ragu-ragu mengungkapkan kalimat yang dibuat sendiri.

Refleksi. Secara keseluruhan kegiatan perkuliahan berjalan lancar. Aktivitas mahasiswa kurang merata. Aktivitas masih didominasi enam mahasiswa (29\%). Kecenderungan mahasiswa diam dapat diasumsikan ketidaksiapan mereka untuk melaksanakan kegiatan perkuliahan Grammaire 4. Dengan demikian kendala yang ditemui, yaitu: (1) kurangnya kesiapan mahasiswa dalam melaksanakan aktivitas perkuliahan, (2) kurang antusias untuk menjawab pertanyaan, dan (3) keraguan mahasiswa untuk mengungkapkan kalimatnya. Permasalahan dalam pratindakan ini dicari jalan keluarnya pada tahap siklus berikutnya, yakni dengan model pembelajaran inquiry.

\section{Pelaksanaan Tindakan Siklus Pertama}

Perencanaan Siklus Pertama. Berdasarkan hasil observasi tersebut peneliti dan kolaborator melaksanakan diskusi dan hasil diskusi sebagai berikut. Pertama, peneliti dan kolaborator mempunyai persamaan persepsi terhadap permasalahan kelas E dan J. Kedua, penyebab terjadinya permasalahan dalam kegiatan perkuliahan Grammaire 4 telah teridentifikasi oleh peneliti dan kolaborator. Ketiga, peneliti dan kolaborator merancang pelaksanaan pemecahan masalah dan menentukan un- 
tuk menggunakan model inquiry yang diyakini membawa perubahan dalam pembelajaran Grammaire 4. Keempat, peneliti dan kolaborator menentukan pelaksanaan penelitian tindakan kelan siklus pertama dimulai hari Selasa, 10 Mei 2016 dilanjutkan pada hari Selasa, 17 Mei 2016. Kelima, peneliti dan kolaborator membuat skenario kegiatan perkuliahan Grammaire 4 dengan menggunakan langkah-langkah pembelajaran model inquiry yang dirumuskan oleh Dell' Olio dan Donk (2007: 330-335), yaitu: 1) developing a question, 2) generating a hypothesis, 3) developing an experimental design, 4) collecting and recording data, 5) analyzing data, 6) reaching conclusions, forming and extending generalizations, 7) communicating results.

Pelaksanaan Tindakan Siklus Pertama. Berdasarkan hasil observasi dan diskusi peneliti dan kolaborator menetapkan tindakan, yaitu melaksanakan perkuliahan Grammaire 4 dengan dengan materi subjonctif passé dengan model inquiry yang meliputi tujuh tahapan sebagaimana yang telah direncanakan. Berikut uraian pelaksanaan tindakan siklus pertama.

Siklus pertama penelitian dilakukan pada Selasa 10 Mei 2016 pada pukul 09.2011.00 dan Selasa 17 Mei 2016 pada pukul 07.30-09.10. Pertemuan selama 50 menit dan masing-masing dimulai dengan pre- test selama 25 menit dan diakhiri dengan post-test selama 25 menit.

Tindakan Pertama Pertemuan Pertama, Selasa 10 Mei 2016. Peneliti membuka perkuliahan di kelas $\mathrm{J}$ dengan mengingatkan mahasiswa bahwa perkuliahan menggunakan tujuh tahapan dari model pembelajaran inquiry sebagai berikut.

Developing a question. Mahasiswa diarahkan agar menggunakan pengetahuan konjugasi kata kerja yang sudah dimiliki. Tiga mahasiswa mengaitkan subjonctif passé dengan passé-composé. Kemudian mahasiswa mengembangkan pertanyaan/pemasalahannya sendiri. Pertanyaan yang diajukan, yaitu: 1) Apakah subjonctif passé merupakan salah satu bentuk konjugasi ganda (conjugaison composée)?,2) Apa sajakah karateristik dari subjonctif passé?, 3) Apa yang dilakukan agar dapat berekspresi dengan menggunakan kalimat dengan subjonctif passé?.

Generating a hypothesis. Mahasiswa menggunakan pengetahuan yang dimiliki yakni passé-composé dan subjonctif présent serta pemahaman terkait dengan pertanyaan pada tahap developing question mahasiswa menghasilkan hipotesis mereka. Hipotesis yang diajukan oleh rombongan belajar (rombel) 1, yaitu "Jika subjonctif passé merupakan salah satu bentuk conjugaison composée maka auxiliaire-nyalah yang dikonjugasikan dengan bentuk subjonctif présent".

Developing an experimental design. Mahasiswa mendesain percobaan mereka untuk menguji hipotesis dan membantu mereka untuk membangun konsep kognitif tentang subjonctif passé. Mahasiswa menghasilkan sistem yang dapat dilaksanakan agar pencatatan data efisien dan efektif.

Collecting and recording data. Mahasiswa mengumpulkan dan mencatat data yakni kalimat yang mengandung subjonctif passé. Data diperoleh dari situs buku ajar maupun teks dari peneliti.

Analyzing data. Mahasiswa menganalisis data baik data yang dikumpulkan sendiri maupun data yang diberikan oleh peneliti, kemudian menjawab pertanyaan inquiry mereka. Dalam kelompok kecil mahasiswa menganalisis bentuk, makna dan fungsi subjonctif passé yang terdapat dalam teks.

Reaching conclusions, forming and extending generalizations. Mahasiswa membandingkan hasil yang ditemukan dengan hipotesis yang mereka buat pada awal perkuliahan. Kesebelas mahasiswa menyatakan ekperimen mereka bermanfaat untuk membangun konstruk kognisi karena dengan menganalisis secara berkelompok mempermudah pemahaman tentang subjonctif passé. Hasil temuan mereka dapat membantu dalam penerapan nyata karena mereka dapat menyelesaikan latihanlatihan yang diberikan oleh dosen. Mahasiswa menemukan solusi bahwa untuk menggunakan subjonctif passé selain memahami fungsinya juga harus menguasai pembentukan subjonctif passé dengan mengingat ke-14 kata kerja yang konjugasi dengan auxiliare être pada conjugaison composée. 
Communicating results. Mahasiswa mengkomunikasikan hal yang telah mereka pelajari melalui presentasi per kelompok 3 mahasiswa. Untuk mengkomunikasikan hal yang telah dipelajari dilaksanakan dengan presentasi.

Tindakan Pertama Pertemuan kedua, 17 Mei 2016. Kelas E sebagai rombel 1 juga dilaksanakan dalam tujuh aktivitas berikut ini.

Developing a question. Mahasiswa diberi kesempatan untuk menebak subjonctif passé termasuk dalam conjugaison simple atau conjugaison composée. Berdasarkan jawaban bahwa subjonctifpassé termasuk dalam conjugaison composée, mahasiswa mengembangkan pertanyaan/ pemasalahannya sendiri. Pertanyaan yang diajukan, yaitu: 1) Mengapa subjonctif passé dikatakan berkonjugasi ganda (conjugaison composée)?, 2) Apa sajakah karateristik dari subjonctif passé?, 3) Apa yang dilakukan agar dapat membuat kalimat dengan subjonctif passé dengan tepat?

Generating a hypothesis. Mahasiswa menggunakan pengetahuan passé-composé dan subjonctif présent serta pemahaman terkait dengan pertanyaan pada tahap developing question untuk mengajukan hipotesis mereka. Hipotesis yang diajukan oleh rombel 1 , yaitu "Jika subjonctif passé merupakan salah satu bentuk conjugaison compoée maka auxiliairenyalah yang dikonjugasikan dengan bentuk subjonctif présent."

Developing an experimental design. Mahasiswa mendesain percobaan mereka untuk menguji hipotesis dan membantu mereka untuk membangun konsep kognitif tentang subjonctif passé. Mahasiswa menemukan sistem agar pencatatan data efisien dan efektif.

Collecting and recording data. Mahasiswa mengumpulkan dan mencatat data yakni kalimat yang mengandung subjonctif passé. Data diperoleh dari situs buku ajar maupun teks dari peneliti.

Analyzing data. Mahasiswa menganalisis data yang dikumpulkan sendiri maupun yang diberikan oleh peneliti, kemudian menjawab pertanyaan inquiry mereka. Dalam kelompok kecil mahasiswa menganalisis bentuk, makna, dan fungsi subjonctif passé yang terdapat dalam teks.
Reaching conclusions, forming and extending generalizations. Mahasiswa membandingkan hasil yang ditemukan dengan hipotesis yang mereka buat pada awal perkuliahan. Kesepuluh mahasiswa menyatakan ekperimen mereka bermanfaat untuk membangun konstruk kognisi karena dengan menganalis secara berkelompok mempermudah pemahaman tentang subjonctif passé. Hasil temuan mereka dapat membantu dalam penerapan secara nyata karena mereka dapat menyelesaikan latihanlatihan yang diberikan oleh dosen. Dengan subjonctif passé selain memahami fungsinya mereka harus menguasai 14 kata kerja yang dikonjugasi dengan auxiliaire être dan sebagian dari keempat belas kata kerja tersebut dikonjugasi denga auxiliare avoir ketika berfungsi sebagai kata kerja transitif.

Communicating results. Mahasiswa mengkomunikasikan hal yang telah mereka pelajari melalui presentasi per kelompok 3 mahasiswa. Untuk mengkomunikasikan hal yang telah dipelajari dengan presentasi.

Observasi Tindakan Pertama. Pada tindakan rombel 2 (10 Mei 2016), jumlah mahasiswa yang hadir 11 orang. 1 mahasiswi dan 2 mahasiswa terlambat. 8 dari sebelas mahasiswa berkontribusi aktif sehingga 3 mahasiswa yang lainnya juga aktif mulai pada tahap ke-4 (collecting and recording data) sampai dengan ke-7 (communicating results) kesembilan mahasiswa aktif, berinteraksi dalam kelompok kecil (2 atau 3 mahasiswa) maupun interaksi antarkelompok membantu pemahaman materi. Hambatan yang ditemui peneliti yaitu kurangnya waktu sehingga perkuliahaan ditambah 20 menit.

Pada rombel 1 (17 Mei 2016) terdapat beberapahambatan yaitu: 1) mahasiswa nampak kurang siap sehingga peneliti mengajukan pertanyaan sebagai umpan agar tahap pertama dapat terlaksana, 2) membutuhkan waktu melebihi yang direncanakan.

Aktivitas belajar mahasiswa yang diamati meliputi: perencanaan pembelajaran, kemajuan aktivitas belajar, dan refleksi terhadap materi yang dipelajari. Rerata pencapaian keaktifan belajar mahasiswa pada ketiga kegiatan disajikan pada gambar 3. Data statistik pada gambar 3 menunjukkan bahwa rerata 
keaktifan mahasiswa dalam proses pembelajaran siklus pertama yang perlu ditingkatkan, yaitu perencanaan pembelajaran dan refleksi materi yang telah dipelajari.

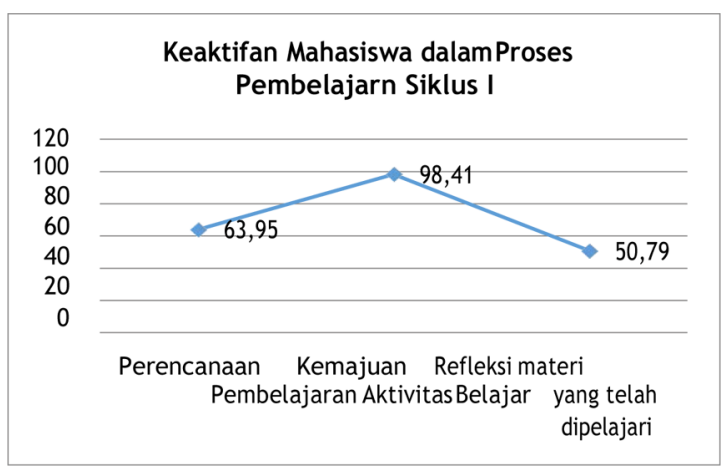

Gambar 3. Persentase Rerata Pencapaian Keaktifan Mahasiswa pada Siklus I

Tabel 1 memberi informasi penggunaan model pembelajaran inquiry pada perkuliahan
Grammaire 4, yaitu: 1) Kemajuan aktivitas belajar mahasiswa dapat dicapai secara optimal, 2) Pencapaian perencanaan belajar mahasiswa masih memerlukan peningkatan karena rerata keaktifan masih di bawah target keberhasilan proses, yakni $70 \%$, dan 3) Kemampuan merefleksi terhadap materi yang telah dipelari untuk memperkuat inquiry-nya merupakan kemampuan proses belajar yang belum tercapai dan masih jauh dari hasil yang diharapkan yakni rerata pencapaian $70 \%$.

Refleksi Siklus Pertama. Analisis dan sintesis hasil observasi dan catatan lapangan menghasilkan refleksi oleh peneliti dan kolaborator serta diskusi dengan mahasiswa setelah siklus I menyimpulkan hal-hal berikut.

Pada developing a question mahasiswa memerlukan arahan untuk mengaitkan materi yang sedang dipelajari dengan pengetahuan yang telah dimiliki sehingga terjadi proses

Tabel 1. Pencapaian Keaktifan Mahasiswa per Individu pada Penggunaan Model Pembelajaran Inquiry pada Siklus Pertama.

\begin{tabular}{|c|c|c|c|c|c|}
\hline \multirow[b]{2}{*}{ Subjek } & \multicolumn{3}{|c|}{ Skor } & \multirow[b]{2}{*}{$\begin{array}{l}\text { Jml } \\
\text { Skor }\end{array}$} & \multirow[b]{2}{*}{$\%$} \\
\hline & $\begin{array}{l}\text { Perencanaan } \\
\text { Pembelajaran }\end{array}$ & $\begin{array}{c}\text { Kemajuan Aktivitas } \\
\text { Belajar }\end{array}$ & $\begin{array}{l}\text { Refleksi Materi } \\
\text { yang } \\
\text { Telah Dipelajari }\end{array}$ & & \\
\hline M1 & 2 & 3 & 1 & 6 & $60 \%$ \\
\hline M2 & 4 & 3 & 2 & 9 & $90 \%$ \\
\hline M3 & 2 & 3 & 1 & 6 & $60 \%$ \\
\hline M4 & 3 & 3 & 1 & 7 & $70 \%$ \\
\hline M5 & 3 & 3 & 1 & 7 & $70 \%$ \\
\hline M6 & 4 & 3 & 2 & 9 & $90 \%$ \\
\hline M7 & 4 & 3 & 1 & 8 & $80 \%$ \\
\hline M8 & 2 & 3 & 1 & 6 & $60 \%$ \\
\hline M9 & 3 & 3 & 2 & 8 & $80 \%$ \\
\hline M10 & 2 & 3 & 2 & 7 & $70 \%$ \\
\hline M11 & 3 & 3 & 2 & 8 & $80 \%$ \\
\hline M12 & 2 & 3 & 1 & 6 & $60 \%$ \\
\hline M13 & 1 & 3 & 1 & 5 & $50 \%$ \\
\hline M14 & 1 & 3 & 2 & 6 & $60 \%$ \\
\hline M15 & 3 & 3 & 1 & 7 & $70 \%$ \\
\hline M16 & 4 & 3 & 3 & 10 & $100 \%$ \\
\hline M17 & 3 & 3 & 1 & 7 & $70 \%$ \\
\hline M18 & 0 & 3 & 2 & 5 & $50 \%$ \\
\hline M19 & 4 & 2 & 2 & 8 & $80 \%$ \\
\hline M20 & 1 & 3 & 2 & 6 & $60 \%$ \\
\hline M21 & 3 & 3 & 1 & 7 & $70 \%$ \\
\hline $\mathrm{Jml}$ & 53 & 62 & 32 & 149 & 1490 \\
\hline $\begin{array}{c}\text { Persentase } \\
\text { Rata-rata Kelas }\end{array}$ & $63.95 \%$ & $98.41 \%$ & $50.79 \%$ & $7.095 \%$ & $70.95 \%$ \\
\hline
\end{tabular}


asimilasi. Kesiapan mahasiswa untuk mengikuti perkuliahan melancarkan proses perkuliahan.

Tahapan collecting and recording data, analyzing data nampak sangat membantu mahasiswa menguasai subjonctif passé sehingga mahasiswa bersemangat melanjutkan tahapan berikutnya. Bagi dosen, kedua tahapan tersebut merupakan aktivitas yang membuat mahasiswa banyak berkontribusi dalam proses pembelajaran. Aktivitas untuk merefleksi terhadap materi yang dipelajari untuk menguatkan inquirynya khususnya pada indikator yang ke-3, yakni menyatakan bahwa langngkah-langkah inquiry yang dilakukan memandu mereka untuk mengatasi permasalahan baru yang ditemui perlu ditingkatkan agar mahasiswa menyadari manfaat langngkah-langkah inquiry dalam pembelajaran tata bahasa Prancis.

Tabel 2. Peningkatan Skor Tata Bahasa Prancis Mahasiswa pada Siklus I

\begin{tabular}{ccc}
\hline Subjek & $\begin{array}{c}\text { Skor } \\
\text { Pratindakan }\end{array}$ & $\begin{array}{c}\text { Skor Siklus } \\
\text { Pertama }\end{array}$ \\
\hline M1 & 31.25 & 65 \\
M2 & 31.25 & 80 \\
M3 & 76.25 & 100 \\
M4 & 41.25 & 70 \\
M5 & 40 & 90 \\
M6 & 81.25 & 90 \\
M7 & 31.25 & 76 \\
M8 & 41.25 & 80 \\
M9 & 30 & 67.5 \\
M10 & 61 & 85 \\
M11 & 37.5 & 100 \\
M12 & 37.5 & 74 \\
M13 & 40 & 87 \\
M14 & 37.5 & 93 \\
M15 & 37.5 & 62 \\
M16 & 60 & 85 \\
M17 & 48.5 & 80 \\
M18 & 65.25 & 100 \\
M19 & 77.5 & 90 \\
M20 & 50 & 75 \\
M21 & 30 & 90 \\
\hline Jum1ah & 98.59 & 1735 \\
\hline Skor rerata & 46.95 & 82.83 \\
kelas & & 35.88 \\
\hline & Peningkatan & \\
\hline & & \\
\hline
\end{tabular}

Keberhasilan dan Kekurangan Siklus Pertama. Perencanaan perkuliahan telah didiskusikan bersama kolaborator. Perencanaan perkuliahan meliputi pembagian waktu, materi dan teknik pembelajaran. Pada siklus pertama perencanaan materi dan teknik pembelajaran berlangsung sesuai perencanaan. Rerata pencapaian proses belajar 70,95\% sudah mencapai target yang diharapkan (70 \%). Jumlah mahasiswa yang sudah mencapai target 13 orang (67 $\%)$.

Target pencapaian skor rata rata mahasiswa 71 sudah tercapai. Jumlah mahasiswa yang telah mencapai target 17 orang $(80.95 \%)$ sedangkan yang belum mencapai target 4 orang (19.05\%). Peningkatan rerata skor dari pre-test dan post-test adalah 35.88 .

Tabel 3. Perbandingan Data Statistik Pre-test dan Post-test Kompetensi Tata Bahasa Prancis Siklus 1

\begin{tabular}{lcc}
\hline \multicolumn{1}{c}{ Data } & Skor Pre-test & Skor Post-test \\
\hline N & 21 & 21 \\
Skor Terendah & 30 & 62 \\
Skor Tertinggi & 81.25 & 100 \\
Mean & 46.95 & 82.83 \\
SD & 16.61 & 11.36 \\
\hline
\end{tabular}

Data statistik pada tabel 3 menunjukkan bahwa : (1) skor rata-rata lebih tinggi daripada skor ketuntasan belajar mahasiswa, (2) model inquiry dapat meningkatkan kompetensi tata bahasa Prancis.

Pada siklus pertama perkuliahan rombel 1 mahasiswa belum memahami tahapantahapan pada model inquiry oleh karena peneliti tidak dapat mengoptimalkan perkuliahan dengan model inquiry dengan alokasi tatap muka perkuliahan 2 SKS yang berdurasi 100 menit.

\section{Pelaksanaan Tindakan Siklus Kedua}

Perencanaan Siklus Kedua. Pertama, pre-test dan post-test dilaksanakan di luar jadwal perkuliahan Grammaire 4 kelas E dan J. Kedua, peneliti memberikan arahan agar mahasiswa mengaitkan materi yang sedang dipelajari dengan pengetahuan yang telah dimiliki agar terjadi proses asimilasi sehingga memudah- 
kan pemahaman terhadap materi yang sedang dipelajari. Ketiga, peneliti memberikan arahan tentang manfaat langkah-langkah inquiry yang dilakukan dapat memandu mereka untuk mengatasi permasalahan baru dalam pembelajaran Tata Bahasa Prancis.

Pelaksanaan Siklus Kedu. Penelitian dilakukan pada Selasa 24 Mei 2016 pukul 07.30-09.10 dan Kamis, 26 Mei 2016 pukul 07.30-09.10. Pre-test selama 25 menit pada Senin, 23 Mei 2016 dan post-test selama 25 menit dilaksanakan pada Jumat 27 Mei 2016. Materi perkuliahan siklus kedua ini pronom relatif composée.

Tindakan Siklus II Pertemuan Pertama, 24 Mei 2016. Masing-masing aktivitas dijabarkan sebagai berikut.

Developing a question. Mahasiswa mengaitkan pronom relatif composé dengan pronom simple. Pertanyaan yang diajukan, yaitu: 1) Mengapa disebut pronom relatif composé?, 2) Apa sajakah karakteristik pronom relatif composé?, 3) Bagaimana teknik mempelajari pronom relatif composé agar kita membuat kalimat dengan benar?

Generating a hypothesis. Dengan menggunakan pengetahuan tentang pronom relatif simple serta pemahaman terkait dengan pertanyaan pada tahap developing a question mahasiswa mengajukan hipotesis mereka. Hipotesis yang diajukan oleh rombel 1, yaitu: 1) "Jika pronom relatif simple tidak menyesuaikan dengan jenis dan jumlah kata benda yang digantikan (antécédent-nya), maka pronom relatif composé menyesuaikannya karena bentuk dasar pronom relatif composé adalah pronom lequel. 2)"Jika di depan pronom relatif qui dapat diberi preposisi, dan pronom relatif où dapat diberi preposisi de dan par, maka selain kedua pronoms relatifs itu penggantinya adalah pronom relatif composé.

Developing an experimental design. Mahasiswa mendesain percobaan mereka untuk menguji hipotesis dan membantu mereka untuk membangun konsep kognitif tentang pronom relatif composé.

Collecting and recording data. Mahasiswa mengumpulkan dan mencatat data yakni kalimat yang mengandung pronom relatif com- posé. Data diperoleh dari situs buku ajar maupun teks dari peneliti.

Analyzing data. Mahasiswa menganalisis data yang dikumpulkan sendiri dan data yang diberikan oleh peneliti, kemudian menjawab pertanyaan inquiry mereka. Dalam kelompok kecil mahasiswa menganalisis pronom relatif composé bentuk, makna, dan fungsi yang terdapat dalam teks.

Reaching conclusions, forming, and extending generalizations. Mahasiswa membandingkan hasil yang ditemukan dengan hipotesis yang mereka buat pada awal perkuliahan. Kesepuluh mahasiswa menyatakan ekperimen mereka bermanfaat untuk membangun konstruk kognisi karena dengan menganalis secara berkelompok mempermudah pemahaman tentang pronom relatif composé. Hasil temuan mereka dapat membantu dalam penerapan secara nyata karena mereka dapat menyelesaikan latihan-latihan yang diberikan oleh peneliti. Mereka menyatakan bahwa untuk dapat menggunakan pronom relatif composé selain memahami fungsinya mereka harus mengingat sejumlah kata kerja yang diikuti oleh preposisi (locutions verbales) agar dapat menggunakan pronom relatif composé dengan tepat.

Communicating results. Mahasiswa mengkomunikasikan hal yang telah mereka pelajari melalui presentasi kelompok (1 kelompok 3 mahasiswa)

Tindakan Siklus II Pertemuan Kedua, 26 Mei 2016. Masing-masing aktivitas dijabarkan sebagai berikut.

Developing a question. Mahasiswa mengaitkan pronom relatif composé dengan pronom relatif simple. Pertanyaan yang diajukan, yaitu: 1) Dapatkah kalimat yang mengandung pronom relatif simple diubah menjadi kalimat yang mengandung pronom relatif composé?, 2) Bagaimana bentuk pronom relatif composé?, 3) Apa sajakah karakteristik pronom relatif composé?, dan 4) Bagaimana teknik mempelajari pronom relatif composé agar kita dapat membuat kalimat dengan benar?

Generating a hypothesis. Hipotesis yang diajukan oleh rombel 1, yaitu: 1) "Bentuk dasar pronom relatif composé adalah pronom lequel oleh karenanya pronom relatif composé 
menyesuaikan dengan jenis dan jumlah kata benda yang digantikan (antécédent-nya), 2) "Jika di depan pronom relatif qui dapat diberi preposisi, dan pronom relatif où dapat diberi preposisi de dan par, pronoms relatif que tidak dapat diberi preposisi, oleh karena itu penggantinya adalah pronom relatif composé.

Developing an experimental design. Mahasiswa mendesain percobaan mereka untuk menguji hipotesis dan membantu mereka untuk membangun konsep kognitif tentang pronom relatif composé.

Collecting and recording data. Mahasiswa mengumpulkan dan mencatat data yakni kalimat yang mengandung pronom relatif composé. Data diperoleh dari situs buku ajar maupun teks dari peneliti.

Analyzing data. Mahasiswa menganalisis data yang dikumpulkan sendiri dan yang diberikan oleh peneliti, kemudian menjawab pertanyaan inquiry mereka. Dalam kelompok kecil mahasiswa menganalisis bentuk, makna, dan fungsi pronom relatif composé yang terdapat dalam teks.

Reaching conclusions, forming and extending generalizations. Mahasiswa membandingkan hasil yang ditemukan dengan hipotesis yang mereka buat pada awal perkuliahan. Sebelas mahasiswa menyatakan ekperimen mereka bermanfaat untuk membangun konstruk kognisi karena dengan menganalis secara berkelompok mempermudah pemahaman tentang pronom relatif composé. Hasil temuan mereka dapat membantu dalam penerapan secara nyata karena mereka dapat menyelesaikan latihanlatihan yang diberikan oleh dosen. Dengan menggunakan pronom relatif composé selain memahami fungsinya mereka harus mengingat sejumlah kata kerja yang diikuti oleh preposisi

Tabel 4. Pencapaian keaktifan mahasiswa per individu pada Penggunaan Model Pembelajaran Inquiry pada Siklus Kedua.

\begin{tabular}{|c|c|c|c|c|c|}
\hline \multirow[b]{2}{*}{ Nama Subjek } & \multicolumn{3}{|c|}{ Skor } & \multirow[b]{2}{*}{$\begin{array}{c}\text { Jumlah } \\
\text { Skor }\end{array}$} & \multirow[b]{2}{*}{$\%$} \\
\hline & $\begin{array}{l}\text { Perencanaan } \\
\text { Pembelajaran }\end{array}$ & $\begin{array}{c}\text { Kemajuan } \\
\text { Aktivitas Belajar }\end{array}$ & $\begin{array}{c}\text { Refleksi Materi } \\
\text { yang Telah Dipelajari }\end{array}$ & & \\
\hline M1 & 2 & 3 & 1 & 6 & $60 \%$ \\
\hline M2 & 4 & 3 & 3 & 100 & $100 \%$ \\
\hline M3 & 3 & 2 & 1 & 6 & $60 \%$ \\
\hline M4 & 4 & 3 & 2 & 9 & $90 \%$ \\
\hline M5 & 4 & 3 & 2 & 9 & $90 \%$ \\
\hline M6 & 4 & 3 & 3 & 10 & $100 \%$ \\
\hline M7 & 4 & 3 & 1 & 8 & $80 \%$ \\
\hline M8 & 2 & 3 & 1 & 6 & $60 \%$ \\
\hline M9 & 3 & 3 & 2 & 8 & $80 \%$ \\
\hline M10 & 3 & 2 & 2 & 7 & $70 \%$ \\
\hline M11 & 3 & 3 & 1 & 7 & $70 \%$ \\
\hline M12 & 2 & 3 & 1 & 6 & $60 \%$ \\
\hline M13 & 4 & 2 & 1 & 7 & $70 \%$ \\
\hline M14 & 2 & 3 & 1 & 6 & 605 \\
\hline M15 & 3 & 3 & 3 & 9 & 905 \\
\hline M16 & 4 & 3 & 2 & 9 & $90 \%$ \\
\hline M17 & 3 & 3 & 3 & 9 & $90 \%$ \\
\hline M18 & 0 & 3 & 3 & 6 & $60 \%$ \\
\hline M19 & 4 & 3 & 3 & 10 & $100 \%$ \\
\hline M20 & 3 & 2 & 1 & 6 & $60 \%$ \\
\hline M21 & 2 & 3 & 1 & 6 & $60 \%$ \\
\hline Jumlah & 66 & 59 & 38 & 166 & 1660 \\
\hline $\begin{array}{c}\text { Persentase Rerata } \\
\text { Kelas }\end{array}$ & $78.57 \%$ & $93.6 \%$ & $60.31 \%$ & $7.904 \%$ & $79.04 \%$ \\
\hline
\end{tabular}


(locutions verbales) agar dapat menggunakan pronom relatif composé dengan tepat.

Communicating results. Mahasiswa mengkomunikasikan hal yang telah mereka pelajari melalui presentasi per kelompok 3 mahasiswa.

Observasi tindakan. Pada hari pertama pada rombel 1 (24 Mei 2016) tidak terdapat hambatan yang ditemui oleh peneliti. Mahasiswa nampak antusias belajar. Suasana kelas hidup mahasiswa nampak ceria dan bersemangat menjalani tahapan-tahapan inquiry.

Hari kedua pada rombel 2 ada keterlambatan empat mahasiswa sehingga kerja kelompok kecil terganggu. Namun karena mahasiswa yang sudah hadir memiliki perencanaan yang bagus dan hambatan dapat diatasi.

Proses belajar mahasiswa yang diamati meliputi: perencanaan pembelajaran, kemajuan aktivitas belajar, dan refleksi terhadap materi yang dipelajari. Pencapaian keaktifan belajar dapat dilihat pada gambar 4, sedangkan pencapaian keaktifan mahasiswa per individu dapat dilihat pada tabel 4 .

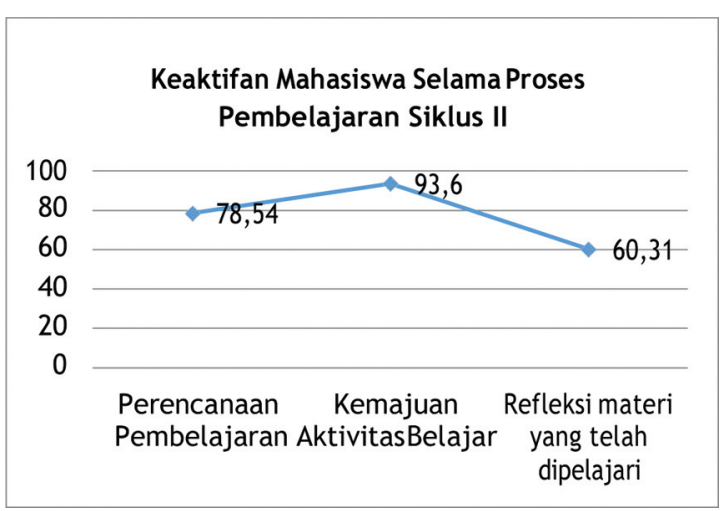

Gambar 4. Persentase Rerata Pencapaian Keaktifan Mahasiswa pada Siklus II

Tabel 5. Perbandingan Data Statistik Pre-test dan Post-test Kompetensi Tata Bahasa Prancis Siklus Kedua

\begin{tabular}{lcc}
\hline \multicolumn{1}{c}{ Data } & Skor Pre-test & Skor Post-test \\
\hline N & 21 & 21 \\
Skor Terendah & 30 & 62 \\
Skor Tertinggi & 81.25 & 100 \\
Mean & 46.95 & 82.83 \\
SD & 16.60640 & 11.36148 \\
\hline
\end{tabular}

Refleksi Siklus Kedua. Pertama, pengalaman mahasiswa pada tahapan-tahapan aktivitas pembelajaran model inquiry pada siklus pertama membantu kelancaran aktivitas pembelajaran pada siklus 2. Kemampuan mahasiswa untuk untuk mengaitkan materi yang sedang dipelajari dengan pengetahuan yang telah dimiliki menunjukkan terjadinya proses asimilasi. Kemampuan ini memperlancar tahapan: developing a question, generating a hypothesis dan developing experimental design.

Kedua, Analyzing data membuat mahasiwa bersemangat menemukan antécédent dan mengurai kalimat yang ditemukan menjadi beberapa kalimat sederhana. Aktivitas ini membuat mahasiswa bersemangat melanjutkan tahapan berikutnya.

Ketiga, penyelesaian latihan-latihan dari buku ajar Echo 2 bukan hanya berfungsi untuk monitoring kemajuan belajar mahasiswa, namun juga sebagai pengayaan untuk memperkuan pencapaian tahapan reaching conclusion, forming and extending generalizations.

Keempat, kesiapan mahasiswa sangat dibutuhkan untuk berkontribusi dalam proses pembelajaran dan ketepatan durasi perkuliahan.

Keberhasilan Siklus Kedua. Pertama, keberhasilan proses siklus kedua. Perencanaan perkuliahan telah didiskusikan bersama kolaborator. Perencanaan perkuliahan meliputi pembagian waktu, materi dan teknik pembelajaran. Pada siklus pertama perencanaan materi dan teknik pembelajaran berlangsung sesuai perencanaan. Rerata pencapaian proses belajar $79.4 \%$ sudah mencapai target yang diharapkan (70\%). Jumlah mahasiswa yang sudah mencapai target 14 orang $(66.66 \%)$.

Keberhasilan produk siklus kedua. Keberhasilan produk diperoleh jika terjadi peningkatan prestasi subjek penelitian sebelum diberi tindakan dan sesudah diberi tindakan. Pada tabel 6 dapat dilihat pencapaian skor hasil belajar mahasiswa dengan memnggunakan model pembelajaran inquiry. 
Tabel 6. Peningkatan Skor Tata Bahasa Prancis Mahasiswa pada Siklus Kedua

\begin{tabular}{ccc}
\hline Subjek & $\begin{array}{c}\text { Skor } \\
\text { Pratindakan }\end{array}$ & $\begin{array}{c}\text { Skor Siklus } \\
\text { Kedua }\end{array}$ \\
\hline M1 & 76 & 76 \\
M2 & 33 & 87 \\
M3 & 53 & 78 \\
M4 & 34 & 77 \\
M5 & 50 & 88 \\
M6 & 48 & 77 \\
M7 & 33 & 81 \\
M8 & 40 & 73.3 \\
M9 & 23 & 90 \\
M10 & 30 & 60 \\
M11 & 30 & 63.3 \\
M12 & 30 & 78.5 \\
M13 & 20 & 63 \\
M14 & 46 & 75 \\
M15 & 23 & 80 \\
M16 & 40 & 83.3 \\
M17 & 30 & 80 \\
M18 & 33 & 87 \\
M19 & 33 & 85 \\
M20 & 40 & 62 \\
M21 & 30 & 77 \\
\hline Jumlah & 762.99 & 1630.39 \\
\hline Skor rerata & 36.333 & 77.638 \\
kelas & & 41.305 \\
\hline \multicolumn{2}{c}{ Peningkatan }
\end{tabular}

Tabel 7. Perbandingan Data Statistik Pre-test dan Post-test Kompetensi Tata Bahasa Prancis Siklus 2

\begin{tabular}{lcc}
\hline \multicolumn{1}{c}{ Data } & Skor Pre-test & Skor Post-test \\
\hline N & 21 & 21 \\
Skor Terendah & 20 & 60 \\
Skor Tertinggi & 76 & 90 \\
Mean & 36.333 & 77.638 \\
SD & 12.4231 & 8.2515 \\
\hline
\end{tabular}

\section{Pembahasan}

\section{Peningkatan Proses Pembelajaran}

Keaktifan mahasiswa merupakan faktor yang penting dalam perkuliahan. Aktivitas dapat diamati dan dapat menunjukkan kesiapan belajar serta kemampuan yang sudah dicapai oleh mahasiswa. Dalam penelitian ini keaktifan mahasiswa termasuk dalam kategori baik (70.47\%) (Suharsimi Arikunto, 2013: 272)). Peningkatan persentase keaktifan mahasiswa yang mencapai kategori sangat baik 6 orang, yang mencapai kategori baik 12 orang, dan dua orang yang mencapai kategori rendah. Pada siklus kedua aktivitas mahasiswa juga meningkat (77.1\%), termasuk dalam kategori baik. Tidak ada mahasiswa yang termasuk dalam kategori rendah. 10 mahasiswa termasuk dalam kategori baik dan 11 mahasiswa termasuk dalam kategori sangat baik. Peningkatan keaktifan mahasiswa merupakan hal yang diperkirakan karena mahasiswa telah mengaplikasikan model inquiry pada siklus pertama.

\section{Peningkatan Produk}

Dalam PTK ini, pada siklus pertama mahasiswa yang memperoleh skor $\geq 71$ berjumlah 17 orang $(80.95 \%)$ dan 4 orang $(19.05 \%)$ belum mencapai skor KKM. Pada siklus kedua 18 mahasiswa $(85.71 \%)$ telah mencapai skor $\geq 71$, dan 3 orang (14.295\%) belum mencapai KKM. Dengan demikian peningkatan jumlah mahasiswa yang mencapai skor KKM bertambah satu orang. PTK ini menggunakan paired samples $t$-test untuk menguji hipotesis dengan taraf signifikasi 0.05 .

Berdasarkan hasil uji-t pada tabel 9 dapat disimpulkan bahwa model inquiry secara signifikan mampu meningkatkan kompetensi tata bahasa Prancis mahasiswa khususnya pada penguasaan subjonctif passé pada siklus pertama. Dengan peningkatan yang signifikan dapat diambil kesimpulan bahwa model inquiry efektif untuk pembelajaran tata bahasa Prancis. Adapun dengan taraf signifikasi 0.05 hasil Uji Paired sample t-test antara skor pre-test terhadap post-test pada siklus pertama diperoleh $\mathrm{p}(0.001)<0.05$.

Tabel 8. Rangkuman Hasil Uji-t Data Pre-test-Post-test Kompetensi Tata Bahasa Prancis Siklus 1

\begin{tabular}{ccccc}
\hline Data & t.hitung & t.tabel & Df & Keterangan \\
\hline Pre-test - Post- test & 11.257 & 2.086 & 20 & $\begin{array}{c}\text { thitung }>\text { ttabel }(11.257>2.086): \\
\text { signifikan }\end{array}$ \\
\hline
\end{tabular}


Tabel 9. Rangkuman Hasil Uji-t Data Pre-test-Post-test Kompetensi Tata Bahasa Prancis Siklus 2

\begin{tabular}{ccccc}
\hline Data & t.hitung & t.tabel & Df & Keterangan \\
\hline Pre-test-Post- test & 13.421 & 2.086 & 20 & $\begin{array}{c}\text { thitung }>\text { t tabel }(13.421>2.086): \\
\text { signifikan }\end{array}$ \\
\hline
\end{tabular}

Berdasarkan hasil uji-t pada tabel 9 dapat disimpulkan bahwa model inquiry secara mampu meningkatkan kompetensi tata bahasa Prancis mahasiswa khususnya pada penguasaan pronom relatif composé pada siklus kedua. Peningkatan yang signifikan menunjukkan bahwa model inquiry berhasil untuk meningkatkan pembelajaran tata bahasa Prancis. Dengan taraf signifikasi 0.05 hasil Uji Paired sample t- test antara skor pre-test terhadap post-test pada siklus kedua diperoleh $\mathrm{p}(0.001)<0.05$.

\section{SIMPULAN}

Hasil penelitian ini telah menunjukkan bahwa dengan mengimplementasikan model inquiry untuk meningkatkan kompetensi tata bahasa Prancis mahasiswa tercapai peningkatan keterlibatan mahasiswa dalam proses belajar dan peningkatan skor hasil belajar diukur dengan pre-test dan post-test.

Pada siklus pertama rerata aktivitas belajar mahasiswa mencapai kategori baik (70.47). Keaktifan mahasiswa meliputi: perencanaan pembelajaran, kemajuan aktivitas belajar, dan refleksi materi yang dipelajari untuk memperkuat inquiry-nya. Aspek ketiga yakni refleksi materi yang dipelajari untuk memperkuat inquiry-nya (50.79) belum mencapai kategori baik. Keterlibatan mahasiswa meningkat pada siklus kedua dengan rerata (77.1). Aspek ketiga meningkat (58.7) namun belum mencapai kategori baik.

Hasil pembelajaran yang diukur melalui pre-test dan post-test menunjukkan adanya peningkatan skor rata-rata dengan perbedaan yang signifikan karena pada siklus pertama hasil penghitungan uji-t pada signifikasi 0.05 skor pre-test dan post-test memperoleh $\mathrm{t}_{\text {hitung }}>\mathrm{t}_{\text {tabel }}$ (11.257> 2.086). Siklus kedua memperoleh $\mathrm{t}_{\text {hitung }}>\mathrm{t}_{\text {tabel }}(13.421>2.086)$.

\section{DAFTAR PUSTAKA}

Budiningsih, C.A. (2005). Belajar dan Pembelajaran. Jakarta: Rineka Cipta.
Conseil de l'Europe. (2001). Cadre Européen Commun de Référence pour les Langues. Paris: Didier.

Cuq, J. P. (1996). Une Initiation à la Didactique de la Grammaire en FLE. Paris: Didier.

Dell'Olio, J. M. and Donk, T. (2007). Models of Teaching: Connecting Studen Learning With Standard. London: Sage Publications, Inc.

Galisson, R. and Coste R. (1976). Dictionnaire de Didactique des Langues. Paris: Librairie Hachette.

Girardet, J. et PecheurJ. (2008). Echo 2: livre de l'élève. Paris: CLE International.

Girardet, J. et PecheurJ. (2008). Echo 2: cahier d'exercices. Paris: CLE International.

Joyce, B. et al. (2004). Models of Teaching ( $7^{\text {th }}$ ed.). Boston: Allyn and Bacon.

Joyce, B. et al. (2016). Models of Teaching (9th ed.). USA: Pearson Education, Inc Diterjemahkan oleh Rianayati Kusminim Pancasari. Yogyakarta: Pustaka Pelajar.

Kuhlthau. (2010). Guided Inquiry. J School Libraries Woldwide, 16 (1).

Madya, S. (2011). Teori dan Praktik Penelitian Tindakan. Bandung: Alfabeta. Moleong, L. J. (2014). Metodologi Penelitian Kualitatif. Bandung: Rosdakarya.

Student Achivement Divisions. 2013. Capacity Buiding Series. Diakses pada 23 September 2014 dari: www.edu.gov.on.ta/ eog/literacynumeracy/inspire/.

Suharsimi, A. (2013). Prosedur Penelitian: Suatu Pendekatan Praktik. Jakarta: Rineka Cipta.

Suryaman, M. (2012). Metodologi Pembelajaran Bahasa. Yogyakarta: UNY PRESS.

Tagliante, C. (2006). La Classe de Langue. Paris: CLE International. 